Case Report / Olgu Sunumu

\title{
A rare cause of acute abdomen: ruptured acquired jejunoileal diverticulitis in a patient with Crohn's disease
}

\author{
Nadir bir akut karın nedeni: Crohn hastalığına bağlı olarak oluşan \\ jejunoileal divertikülit rüptürü
}

\section{Ali Kağan Gökakını, Mustafa Atabey1, Orhan Üreyen2, Özcan Altınel2, Eyüp Sabri Tezcan2}

1Department of General Surgery, Cumhuriyet University School of Medicine, 58140 Sivas 2Department of General Surgery, Gülhane Military Medical Academy, Ankara;

\section{Abstract}

The objective of case report is to present a case of ruptured acquired jejunoileal diverticulitis in a patient with acquired small intestinal diverticulosis and Crohn's disease. Acquired small intestinal diverticulosis are extremely rare clinical entities. They only become surgically relevant when the complications such as diverticulitis, perforation and bleeding occurs. Crohn's disease has been reported to be in close association with several small intestine pathologies including Meckel's diverticulum. However, the association between Crohn's disease and acquired small intestinal diverticulosis has not been reported previously. The patient was 35-year-old man. Three days ago before admission, by means of colonoscopy and biopsy, he was diagnosed as having Crohn's disease and begun to use a treatment for this disease. On admission, he complained about abdominal pain. Ultrasonography revealed that there was free fluid in all quadrant of abdominal cavity. The patient was referred for surgery. At laparotomy, there was multiple diverticulosis in small intestine from ileocecal valve to Treitz .One of them was ruptured. We performed segmental small bowel resection and end-to-end anastomosis. He was discharged uneventfully. As a conclusion this case suggests that small intestinal diverticulosis and its complications may be associated with Crohn's disease and should be considered in the differential diagnostic workup and surveillance of patients with gastrointestinal disorders. Imaging studies including entroclysis, technetium scan (for exclusion of Meckel's diverticulum) and computerized tomography may be useful to make a definitive diagnosis of both the Crohn's disease and diverticulosis. However, some patients may require laparotomy not only for a final diagnosis but also for the complications.

Keywords: Crohn's disease, diverticulosis, diverticulitis, rupture

Özet

Bu olgu sunumunun amacı Crohn hastalığı ve edinsel ince bağırsak divertikülozu olan bir hastada gelişen jejenoileal divertikülit perforosyonunu sunmaktır. Edinsel ince bağırsak 
divertikülozu oldukça nadir görülen bir klinik durumdur. Cerrahinin gündemine yalnızca divertikülit, perforasyon ve kanama gibi komplikasyonlar ortaya çıktığında gelir. Crohn hastalığını Meckel divertikülü gibi bası ince bağırsak hastalıkları ile olan yakın ilişkisi daha önceden bildirilmiştir. Ancak, Crohn hastalığı ile edinsel ince bağırsak divertikülozu ilişkisi daha önce gösterilmemiştir. Karın ağrısı şikayeti ile başvuran 35 yaşında erkek hastanın hikayesinden üç gün önce kolonoskopi ve biyopsi neticesinde Crohn hastalığı teşhisi konulduğu ve bu hastalığa yönelik tedaviye başlandığı öğrenildi. Yapılan abdominal ultrasonografide batın içi tüm kadranlarda serbest sıvı görülmesi üzerine hasta cerrahi kararı alındı. Laparatomide ileoçekal valfden Treitz ligamanına kadar ince bağırsakda multiple divertiküller görüldü. Bu divertiküllerden birinde rüptür mevcuttu. Hastaya segmenter ince bağırsak rezeksiyonu ve uç uca anastomoz yapıldı. Operasyon sonrası dönem olaysız geçti ve hasta taburcu edildi. Sonuç olarak bu olgu ince bağırsak divertikülozu ve komplikasyonlarının Crohn hastalığı ile ilişkisi olabileceğini gastrointestinal sistem yakınmaları olan hastalara yaklaşımda ve teşhis çalışmaları esnasında bu durumun göz önüne alınması gerektiğini düşündürdü. Entroklisiz, teknesyum taraması ( Mekel divertikülünü dışlamak için) ve abdominal tomografi Crohn hastalığı ve ince bağırsak divertikülozu kesin tanısında yararlı olabilir. Ancak bazı hastalarda gerek tanı gerekse de komplikasyonları tedavi etmek amacı ile laparatomi gerekebilir.

Anahtar sözcükler: Crohn hastalığı, divertikülozis, divertikülitis, rüptür

\section{Introduction}

Acquired jejunoileal diverticulosis is one of the rare clinical entities in general surgery practice $(1,2)$. Diverticula usually found in multiple numbers with a mean number of ten to fifteen; however, diverticulum may be solitary or in some patients diverticula may even found up to a hundred $(3,4)$. From jejunum to terminal ileum, the incidence and size of diverticula has been reported to be decreased. They are always situated on the mesenteric border of the small intestine $(3,4)$.

The majority of cases have been reported as asymptomatic or as associated with nonspecific gastro-intestinal symptoms. However, they may be surgically relevant for the acute complications including diverticulitis, hemorrhage, mechanical obstruction and perforation (5). The most common complication of the small bowel diverticulosis has been reported to be diverticulitis, which often presents with non-specific symptoms or with features that may mimic other symptom complexes including appendicitis, colonic diverticulitis, or Crohn's disease (4).

An association between Crohn's disease and jejunoileal diverticulosis has not been reported previously. However, Crohn's disease has been reported to be associated with Meckel's diverticulum (6) Also, it has been reported to result in several gastrointestinal changes including motility and serosal connective tissue changes that are considered to be the important factors in the development of diverticula. $(7,8)$

Case

The patient was 35-year-old man. Three days ago before his admission, he was diagnosed as a Crohn's disease by means of colonoscopy and biopsy, and was received a treatment for Crohn's disease. While under the treatment for Crohn's disease, his complications

Gökakun et al. Ruptured acquired jejuno-ileal diverticulitis and Crohn's disease 90

This is an open-access article distributed under the terms of the Creative Common Attribution License, which permits unrestricted use, distribution, and reproduction in any medium, provided the original author(s) and source are credited.

This article may be cited as: Gökakm AK, Atabey M, Üreyen O, Altnel Ö, Tezcan ES. A rare cause of acute abdomen: ruptured acquired jejuno-ileal diverticulitis in a patient with Crohn's disease. Basic Clin Sci 2013; 2: 89-94. Available from: www.bcsciences.com. 
were revealed. On his admission, he complained about severe abdominal pain. He had muscular rigidity and tenderness during abdominal examination. There was no pathologic signs at his plain abdominal X-ray. Blood test showed that white blood cell count was $14.200 / \mathrm{mm} 3$. Other blood tests were in normal range. His temperature was $38.2^{\circ} \mathrm{C}$. Ultrasonography revealed that there was free fluid in all part of his abdominal cavity. At laparotomy, there was multiple diverticulosis in small intestine from ileocecal valve to Treitz ligament. One of them was found as ruptured at the middle of the jejunal area (Fig. 1). We performed segmental small bowel resection and end-to-end anastomosis. He had no complications following surgery. After postop follow-up, the patient was discharged 7 days after the operation uneventfully.
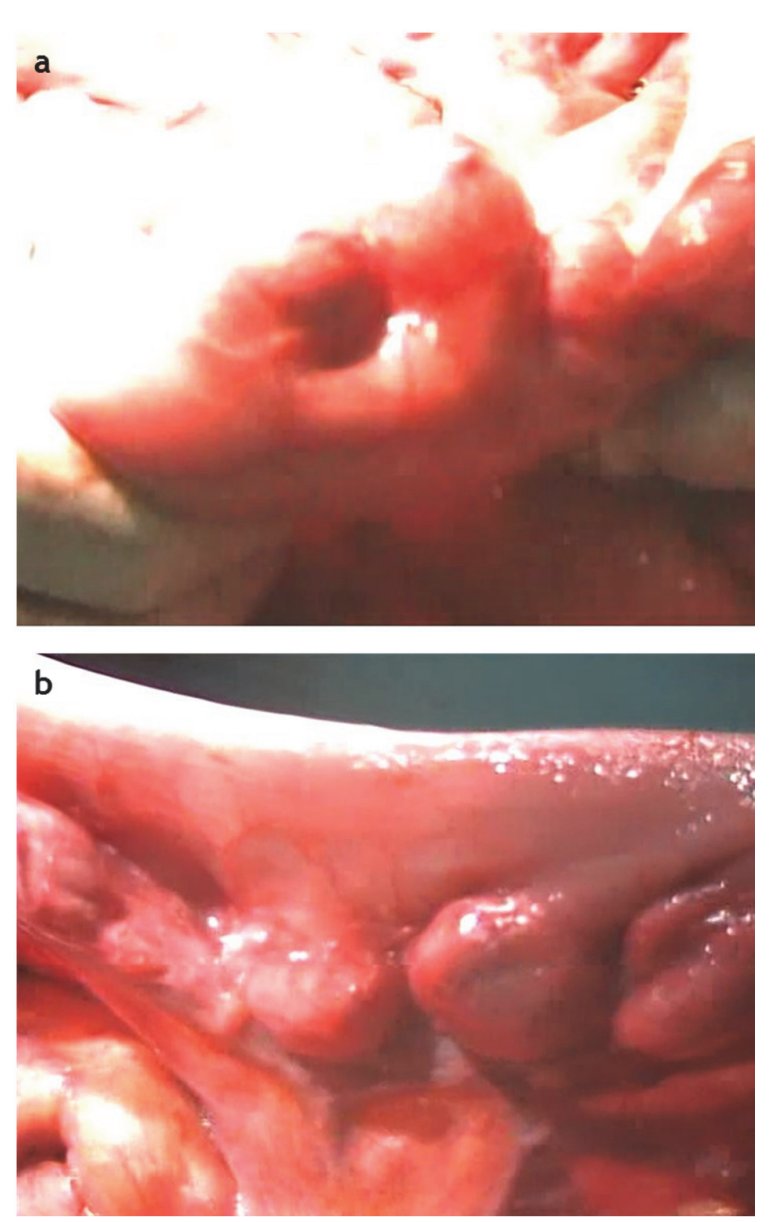

Figure 1. a. Rupture area in jejunum. b. A representative picture of diverticula.

\section{Discussion}

Although acquired jejunoileal diverticulosis was known as one of the rare clinical entities (o.1 to $1.4 \%$ ), their complications are non-exceptional in general surgery practice (6\%-

Gökaknn et al. Ruptured acquired jejuno-ileal diverticulitis and Crohn's disease 91

This is an open-access article distributed under the terms of the Creative Common Attribution License, which permits unrestricted use, distribution, and reproduction in any medium, provided the original author(s) and source are credited.

This article may be cited as: Gökakm AK, Atabey M, Üreyen O, Altnel Ö, Tezcan ES. A rare cause of acute abdomen: ruptured acquired jejuno-ileal diverticulitis in a patient with Crohn's disease. Basic Clin Sci 2013; 2: 89-94. Available from: www.bcsciences.com. 
18\%). Indeed, a death rate which can reach $40 \%$ in older patients has been reported. Acquired jejunoileal diverticulosis have been reported to be slightly higher in men than women. They usually occur in the patients above the age of 40. From a histological view, acquired diverticulosis differ from congenital ones by an absent muscular tunic. Although several factors have been advocated in the pathogenesis of acquired jejunoileal diverticulosis, motility disorders and connective tissue derangements of the intestinal wall are considered to be the primary factors in the development of the disease. Crohn's disease is strongly associated with several motility, serosal connective changes and inflammatory polyps of the small intestine $(7,9)$. In this present case, Crohn's disease may be considered to be one of the factors in the development of the diverticulosis. The diagnosis of the Crohn's disease was made with the presence of nonspecific abdominal pain and diarrhea. And then, colonoscopy was performed and several biopsies were taken. Histologic examination confirmed the diagnosis of Crohn's disease.

Imaging studies including enteroclysis and CT have been reported to be useful in the diagnosis of uncomplicated diverticulosis. These techniques are also effective to diagnose the Crohn's disease. $(4,10)$ Specific findings on the CT for the diverticulosis have been reported previously (4). As reported jejunal diverticula appear on CT as distinct round or ovoid, fluid, contrast, or air-containing structures outside the expected lumen of the small bowel, with a smooth, wall and no recognizable small bowel folds. They are often seen to communicate directly with an adjacent loop of small bowel $(2,4)$. In our case the patient was referred to surgical clinic with severe abdominal pain. He had muscular rigidity and tenderness. There was no pathologic signs at his plain abdominal X-ray. Blood test showed that white blood cell count was $14.200 / \mathrm{mm} 3$. Other blood tests were in normal range. His temperature was $38.2^{\circ} \mathrm{C}$. Ultrasonography revealed that there was free fluid in all part of his abdomen. So we decided to operate him for the differential diagnosis of acute abdomen.

The surgically important complications of the acquired jejunoileal diverticulosis have been reported to be as: (by descending order) diverticulitis, perforation (7\%), acute bowel obstruction (3\%), and intestinal hemorrhage (2.7\%) mostly massive. However, malabsorption of fat and protein, macrocytic anemia and rarely intestinal tumors may be observed. Another complication is that of vitamin B12 malabsorption due to the stagnation and bacterial overgrowth in large diverticula. The asymptomatic patients are generally put on prophylaxis of the complications is based on healthy diet habits against stasis, bowel pressure using antispasmodics, intestinal disinfectants, residue free diet, and against infection (oral tetracyclines). However, the development of the complications merits surgical intervention. Diverticulitis has been reported to be one of the rare causes of acute abdomen, which should be distinguished from some other inflammatory conditions including acute appendisitis, cholecystitis and diverticuilitis of the colon. Diverticular perforation may lead to primary diagnosis of jejuno-ileal diverticulosis. In such condition, the diagnosis is mostly made with laparotomy in the patient without a prior history of diverticulosis.

The diagnosis of perforated diverticulitis may be difficult but can be appreciated with scrolling through the image stack. CT findings include nonspecific signs such as an inflammatory mass containing gas and feces-like material, and edema in the surrounding tissue such as intraperitoneal fat or fascial layers $(5,7)$. More specifically, a focal area of asymmetrical small bowel wall thickening or intraluminal contrast enhanced outpouching on the mesenteric side of the bowel may be seen, the presence of which may be

Gökaknn et al. Ruptured acquired jejuno-ileal diverticulitis and Crohn's disease 92 This is an open-access article distributed under the terms of the Creative Common Attribution License, which permits unrestricted use, distribution, and reproduction in any medium, provided the original author(s) and source are credited.

This article may be cited as: Gökakm AK, Atabey M, Üreyen O, Altmel Ö, Tezcan ES. A rare cause of acute abdomen: ruptured acquired jejuno-ileal diverticulitis in a patient with Crohn's disease. Basic Clin Sci 2013; 2: 89-94. Available from: www.bcsciences.com. 
within or in close proximity to an abscess cavity (5). In our case, perforation was observed in the antimesenteric side of the diverticulum Also, an inflammatory reaction with free infected fluid collection in all parts of abdomen was noted. All parts of colon were intact. Perforation is also a common complication which requires emergent surgical intervention in the course of Crohn's disease. We are not sure whether perforation was caused by Crohn's disease or diverticulitis. But a diverticulum was perforated at the middle of jejunum. This complication is usually treated with primary transvers closure. Limited resection is recommended to decrease anastomotic leakage and intestinal fistulas. However, the perforated diverticulum generally requires complete resection of the diverticulum. We performed segmental resection where diverticula perforated. Pathologic study revealed that the patient was Crohn's disease and diverticula was perforated. Previous reports, which have studied the association of Meckel's diverticulum and Crohn's disease, have advocated the role bacterial overgrowth in the diverticulum may be a predisposing factor for the development of Crohn's disease. $(6,8)$ However, currently no specific data is available for diverticulosis. We believe that no single case may be enough to advocate such a theory. Previously, the role of Crohn's disease in the motility and intestinal connective tissue disturbances was described.

As a conclusion, this case suggests that small intestinal diverticulosis and its complications may be associated with Crohn's disease and should be considered in the differential diagnostic workup and surveillance of patients with gastrointestinal complaints. Imaging studies including entroclysis, technetium scan (for exclusion of Meckel's diverticulum) and CT may be useful to make a definitive diagnosis of both the Crohn's disease and diverticulosis. However, some patients may require laparotomy not only for a final diagnosis but for the complications.

\section{References}

1. Edwards HC. Diverticulosis of the small intestine. Ann Surg. 1936; 103: 230-54.

2. Maglminte DT, Chemish SM, DeWeese A. Acquired jejunoileal diverticular disease: subject review state of the art. Radiol 1986; 158:577-80.

3. Gayer G, Zissin R, Apter S. Acute diverticulitis of the small bowel: CT findings. Abdom Imaging. 1999; 24:452-5.

4. Coulier B, Maldague P. Diverticulitis of the small bowel: CT diagnosis. Abdom Imaging. 2007; 32:228-33.

5. Tsiotos GG, Farnell MB, Ilstup DM. Non-Meckelian jejunal or ileal diverticulosis: an analysis of 112 cases. Surgery. 1994; 116: 726-34.

6. Andreyev HJN, Owen RA, Thompson I, Forbes A. Association between Meckel's diverticulum and Crohn's disease: a retrospective review. Gut. 1994; 35: 788-790

7. Borley NR, Mortensen NJ, Jewell DP, Warren BF. The relationship between inflammatory and serosal connective tissue changes in ileal Crohn's disease: evidence for a possible causative link. J Pathol. 2000;190:196-202.

8. Annese V, Bassotti G, Napolitano G, Usai P, Andriulli A, Vantrappen G. Gastrointestinal motility disorders in patients with inactive Crohn's disease. Scand J Gastroenterol. 1997;32:1107-17.

9. Parasi A, Triantafillidis JK, Barbatzas C, Karakosta A, Condilis N, Sotiriou H. Coexistence of Crohn's disease and inflammatory fibroid polyp of the small bowel. Report of a case and review of the literature.Ann Ital Chir. 2005;76:395-9.

Gökaknn et al. Ruptured acquired jejuno-ileal diverticulitis and Crohn's disease 93 This is an open-access article distributed under the terms of the Creative Common Attribution License, which permits unrestricted use, distribution, and reproduction in any medium, provided the original author(s) and source are credited.

This article may be cited as: Gökakm AK, Atabey M, Üreyen O, Altmel Ö, Tezcan ES. A rare cause of acute abdomen: ruptured acquired jejuno-ileal diverticulitis in a patient with Crohn's disease. Basic Clin Sci 2013; 2: 89-94. Available from: www.bcsciences.com. 
10. Makó EK, Mester AR, Tarján Z, Karlinger K, Tóth G.Enteroclysis and spiral CT examination in diagnosis and evaluation of small bowel Crohn's disease. Eur J Radiol. 2000;35:168-75. 